\title{
Spatial and temporal analysis of stem bleeding disease in coconut palm in the state of sergipe, Brazil
}

\author{
REJANE R. DA COSTA E CARVALHO ${ }^{1}$, PAULO E. DE SOUZA ${ }^{2}$, \\ DULCE R.N. WARWICK ${ }^{3}$, EDSON A. POZZA ${ }^{2}$ and JOSÉ L.S. DE CARVALHO FILHO ${ }^{1}$ \\ ${ }^{1}$ Departamento de Agricultura, Universidade Federal Rural de Pernambuco, \\ Rua Dom Manoel de Medeiros, s/n, Dois Irmãos, 52171-900 Recife, PE, Brasil \\ ${ }^{2}$ Departmento de Fitopatologia, Universidade Federal de Lavras, \\ Campus Universitário, Caixa Postal 3037, 37200-000 Lavras, MG, Brasil \\ ${ }^{3}$ Embrapa Tabuleiros Costeiros, Avenida Beira Mar, 3250, Caixa Postal 44, Jardins, 49025-040 Aracaju, SE, Brasil
}

Manuscript received on September 3, 2012; accepted for publication on April 15, 2013

\begin{abstract}
Stem bleeding disease (resinosis) of coconut palm is caused by Thielaviopsis paradoxa and is very important in the state of Sergipe, Brazil. Understanding the epidemiological behavior of the disease is essential for establishing more efficient control strategies. Thus, we characterized the temporal progression and spatial distribution of stem bleeding in a commercial orchard under conditions of natural infection in the area of Neopolis, Sergipe. Three plots with 729 plants each were selected and evaluated every two months for stem bleeding incidence. In the temporal analysis, the monomolecular model gave the best fit to data on disease incidence, as it accurately showed the temporal dynamics of the disease during the experiment period. The spatial pattern of stem bleeding varied over time, with initial infections presenting random pattern and then evolving to aggregate pattern during evaluations. This indicates that the disease may have originated from the pathogen survival structures, followed by auto infections caused by dissemination from plant to plant, either by humans, by contact between roots, or by the vector Rhynchophorus palmarum.
\end{abstract}

Key words: coconut, epidemiology, stem bleeding, Thielaviopsis paradoxa.

\section{INTRODUCTION}

Coconut palm (Cocos nucifera L.) is one of the most important trees in the world, as it generates employment and income in many countries where its fruit is either eaten raw or processed into manufactured products and by-products. However, many factors such as diseases can reduce crop yield.

Coconut stem bleeding, caused by the fungus Thielaviopsis paradoxa (De Seynes) Höhn, is an

Correspondence to: Rejane Rodrigues da Costa e Carvalho E-mail: rejanercosta@yahoo.com.br important disease for coconut crops. It was first detected in the state of Sergipe in early 2004 and has then become the main concern of producers, researchers, and extension agents due to its rapid spread and subsequent death of infected plants in less than two months. Aggravating the situation, there is strong evidence that the beetle Rhynchophorus palmarum Linnaeus performs as one of the disease vectors in the field (Costa-Carvalho et al. 2011).

The main stem bleeding symptoms are reddishbrown liquid in the stem cracks, which may turn 
blackish when dried; reduced frequency of leaf emergence; reduced size of young leaves; stem thinning near the canopy as disease progresses; brownish-yellow and easily breakable leaves (Warwick and Passos 2009).

Information about spatial and temporal dynamics of stem bleeding is extremely important to better understand the pathosystem, as it can be useful to describe and clarify the disease progression. In addition, this information helps develop sampling plans, plan controlled experiments, and characterize production losses caused by the disease.

Temporal analysis allows building disease progress curves for better representation of the epidemic process. Interpreting these curve shapes and determining their components, such as initial amount of disease, progression rate, final amount of disease, and area under the progress curve are fundamental to manage epidemics (Bergamin Filho 1995).

The study of spatial patterns of plant diseases, which reflects the dispersion process of pathogens characterized by the distribution of sick plants relative to each other, provides helpful data to elucidate the etiology, the role of dissemination agents such as vectors, wind and rain, and to define the most appropriate strategies for disease control. The analysis of spatial arrangement also enables better understanding of the dynamics of epidemics in relation to the pattern of the initial inoculum, the effect of biological and cultural practices, and the effect of environmental factors on the amount of disease in the field (Jeger 1990).

Thus, we characterized the spatial and temporal dynamics of stem bleeding in the main coconut producing region of the state of Sergipe by creating disease progress curves. In addition, we characterized the structure and dynamics of stem bleeding outbreaks and analyzed ordinary runs.

\section{MATERIALS AND METHODS}

The experiments were conducted at the Laboratory of Phytopathology of Embrapa Tabuleiros Costeiros,
Aracaju, and at the União Fruticultura Farm located in Perímetro Irrigado de Neópolis, state of Sergipe, latitude $10^{\circ} 17^{\prime} \mathrm{S}$, longitude $36^{\circ} 35^{\prime} \mathrm{W}$, and altitude $120 \mathrm{~m}$. This property was chosen because it had the first outbreaks in 2009, nearly five years after disease detection in other local plantations.

Temperature data, relative humidity, and total rainfall were obtained daily at the weather station of the Associação dos Concessionários do Distrito de Irrigação do Platô de Neópolis- ASCONDIR, located about $5 \mathrm{~km}$ from the experiment areas.

\section{EVALUATION OF DISEASE}

We selected three homogeneous plots comprising 13-year-old green dwarf coconut palms with 729 plants each. The trees were distributed in 27 rows, 27 columns and planted in equilateral triangle system (7.5 $\mathrm{m}$ side). Disease incidence was assessed every two months during two years, from July 2009 to May 2011, starting from the earliest plants showing stem bleeding symptoms.

All plants in every plot were monitored individually for typical stem bleeding symptoms. We recorded the presence or absence of symptoms, i.e., incidence, and the relative position of each plant to create a map per plot for each evaluation date. Based on these maps we have obtained cumulative incidence maps, which consider that sick plants will remain sick in later assessments.

\section{Disease PROGRESS CURVES}

The progress curves were designed for all plots with values of incidence relative to time. The incidence was determined by the percentage of plants showing stem bleeding symptoms.

Based on the incidence values in proportion (y), we have adjusted the following models: Linear $\left(\mathrm{y}=\mathrm{y}_{0}+\mathrm{r} * \mathrm{t}\right) ;$ Exponential: $\exp \left(\mathrm{x}_{0}\right) * \exp (\mathrm{rt}) ;$ Monomolecular: 1 - $\left(\left(1-\exp \left(\mathrm{x}_{0}\right)\right) /\left(\exp \left(\mathrm{x}_{0}\right)\right)\right)$ * $\exp (-\mathrm{rt}) ;$ Logistics: $1 /\left(1+\left(\left(1 / \exp \left(\mathrm{x}_{0}\right)\right)-1\right) *\right.$ $\exp (-\mathrm{rt})$; and Gompertz: exp (- (-ln (exp (-exp $(\mathrm{x} 0)))) * \exp (-\mathrm{rt}))$. The best-fit model was selected 
taking into account the highest coefficient of determination adjusted in the regression analysis $(R 2)$ for reciprocity between the observed values (independent variable) and predicted values (dependent variable) of disease incidence; the least mean square (LMS); and the absence of trends in the residual plot (Campbell and Madden 1990).

Based on the best-fit model, we determined the linearization to the curve. Then we estimated the onset of the epidemic in each plot and the amount of disease at 660 days.

\section{SPATIAl ARRANGEMENT OF THE DiSEASE}

\section{Analysis of doublet}

The numbers of healthy $(\bullet)$ and sick (x) plants were characterized in the crop rows. The expected number of doublets was calculated under the null hypothesis $\mathrm{E}(D)=\mathrm{m}(\mathrm{m}-1) / \mathrm{N}$, where $D$ : number of doublets, $\mathrm{m}$ : number of sick plants, $\mathrm{N}$ : number of plants in the row. The standard deviation of $D$ under the null hypothesis was calculated by $\mathrm{S}$ $(D)=\{\mathrm{m}(\mathrm{m}-1)[\mathrm{N}(\mathrm{N}-1)+(2 \mathrm{~N}(\mathrm{~m}-2)+\mathrm{N}(\mathrm{m}-2)(\mathrm{m}-3)-$ $\left.(\mathrm{N}-1) \mathrm{m}(\mathrm{m}-1)] / \mathrm{N}^{2}(\mathrm{~N}-1)\right\}^{0.5}$. We calculated the standardized value of $\mathrm{ZD}=[(D+0.5-\mathrm{E}(D)] / \mathrm{s}(D)$ based on normal distribution. When ZD> $1.64(\mathrm{P}=$ $0.05)$, it was defined as aggregate pattern, and when $\mathrm{ZD}<1.64(\mathrm{P}=0.05)$ it was deemed random pattern.

\section{Analysis of dynamics and structure of outbreaks (ADEF)}

Outbreak sources were deemed areas of localized concentration of sick plants, either as primary infection sources or coincident with areas originally favorable to disease development, which tend to influence the later pattern of transmission (Laranjeira et al. 1998).

Only sick plants immediately adjacent in the pattern of vertical, horizontal, or longitudinal closeness shared the same outbreak source. In each plot we counted the number of outbreak sources (NF), number of plants per outbreak source (NPF), number of sick plants in the largest row (IF), and number of sick plants in the largest column (Ic) in each outbreak source. Based on this data we calculated the average number of plants per outbreak source (NMPF), frequency distribution of number of plants per outbreak source (NPF), outbreak shapes (IFF), and compression ratio per outbreak (ICF) using the formulas: IFF= If / Ic and $\mathrm{ICF}=\mathrm{NPF} / \mathrm{If} *$ Ic.

\section{RESULTS AND DISCUSSION}

Average values of temperature, relative humidity, and total rainfall during the experiments were respectively $26^{\circ} \mathrm{C}, 91 \mathrm{~mm}$, and $81.4 \%$. The highest temperatures were recorded in March in both years (approximately $28^{\circ} \mathrm{C}$ ). Rainfall rates showed significant differences during the experiment period. The highest values were obtained in July 2009 and July 2010, 177.3 and $214.4 \mathrm{~mm}$ respectively. Relative humidity ranged from 74.8 to $89.6 \%$ (Figure 1).

\section{Disease PROGRess CURVES}

In all three plots, disease progressed intermittently over the two years with increased incidence of stem bleeding. At the end of the experiment, the highest value of incidence was found in plot 3, which had $22.77 \%$ plants with disease symptoms, followed by plot 1 and 2, with 20.16 and $12.89 \%$ respectively (Figure 2).

Taking into account the coefficient of determination adjusted in the regression analysis (R2), the mean square deviations (Table I) and the residual chart, the monomolecular model best fit the data on stem bleeding incidence among the plots evaluated in the study period. Disease progression rates $(r)$ estimated by the parameter $b$ in the regression equation were $0.0003,0.0002$, and 0.0004 in plots 1,2 and 3 respectively (Figure 2).

In the two-year evaluation, the period from May to September showed the highest rates of rainfall, relative humidity, and lower temperatures rates. 


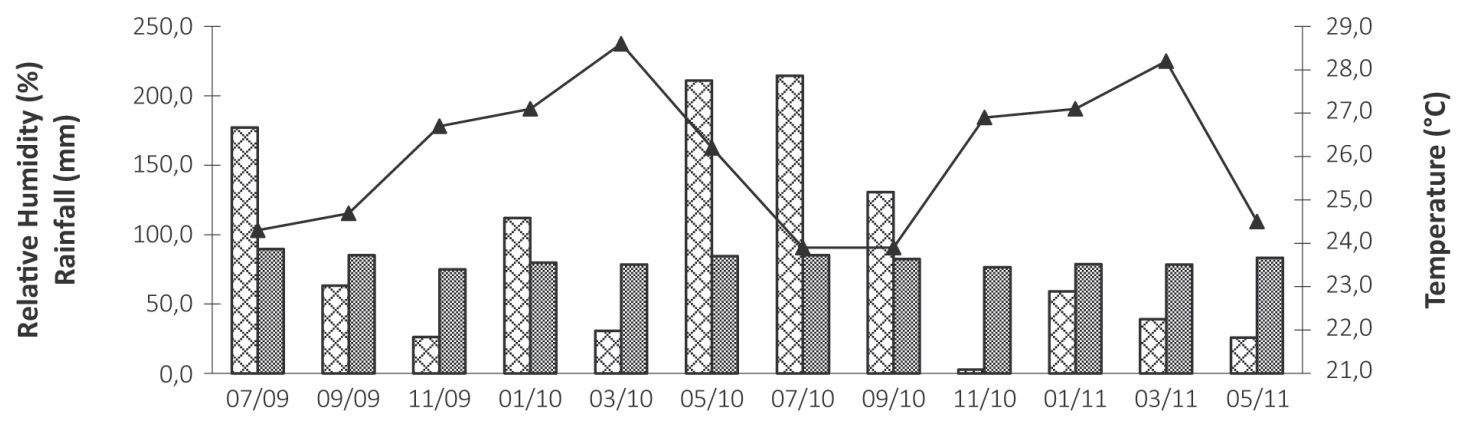

Month/Year

एख Relative Humidity $(\%) \quad \leftarrow$ Temperature $\left({ }^{\circ} \mathrm{C}\right)$

Figure 1 - Average temperature, total rainfall, and relative humidity in Platô de Neópolis, state of Sergipe, from July 2009 to May 2011.

However, disease progression was gradual and constant, and was not influenced by the time of year (Figure 2). This result indicates the great adaptability of pathogens to different environmental conditions, as well as the possibility of involvement of other factors for the occurrence of disease. The lack of correlation between incidence of stem bleeding and climate variables in all plots shows that climatic conditions do not affect disease progress in the case of coconut palms.

Plot 1

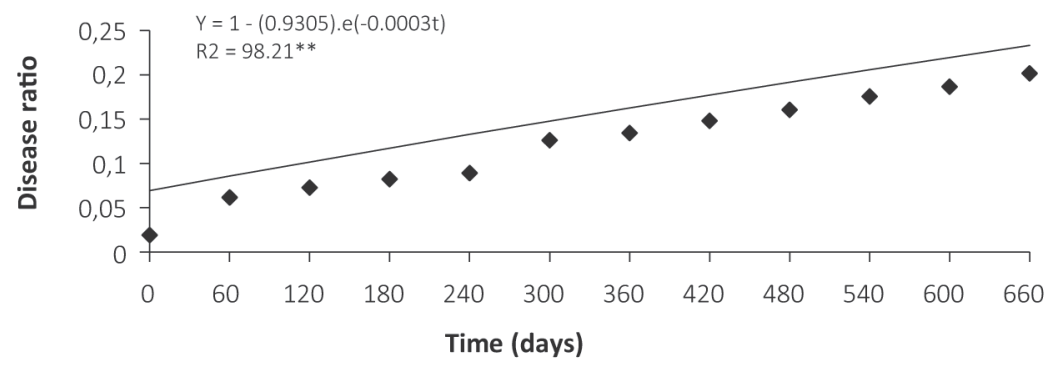

- Real - Monomolecular

Plot 2

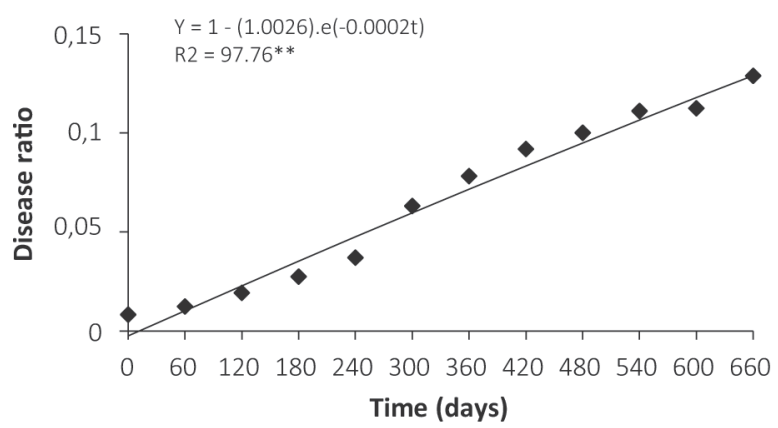

- Real Monomolecular
Plot 3

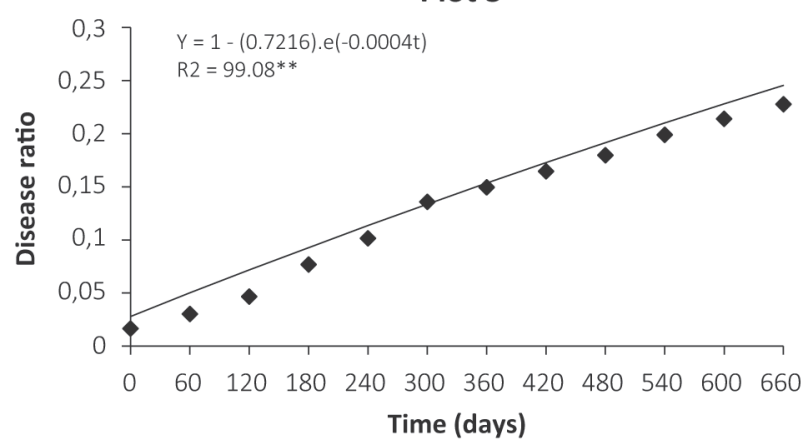

- Real Monomolecular

Figure 2 - Progress curves of incidence of coconut stem bleeding in Platô de Neópolis, state of Sergipe, in plots 1, 2 and 3, adjusted to a monomolecular model. 
TABLE I

Coefficient of determination between predicted and observed values $\left(R^{2}\right)$ and residual mean square $(R M S)$ of models for incidence of coconut stem bleeding in Platô de Neópolis, state of Sergipe.

\begin{tabular}{lcccccc}
\hline \multirow{2}{*}{ Models } & \multicolumn{2}{c}{ Plot 1 } & \multicolumn{2}{c}{ Plot 2 } & \multicolumn{2}{c}{ Plot 3 } \\
\cline { 2 - 7 } & $\boldsymbol{R}^{2}$ & $\boldsymbol{R M S}$ & $\boldsymbol{R}^{2}$ & $\boldsymbol{R M S}$ & $\boldsymbol{R}^{2}$ & $\boldsymbol{R M S}$ \\
\hline Linear & 97.88 & $7.42 \times 10-5$ & 97.67 & $4.87 \times 10-5$ & 98.61 & $8.19 \times 10-5$ \\
Monomolecular & 98.21 & $6.27 \times 10-5$ & 97.76 & $4.93 \times 10-5$ & 99.08 & $5.42 \times 10-5$ \\
Logistic & 91.08 & $3.12 \times 10-4$ & 86.29 & $2.86 \times 10-4$ & 87.78 & $7.19 \times 10-4$ \\
Exponential & 89.05 & $3.83 \times 10-4$ & 84.01 & $3.34 \times 10-4$ & 84.01 & $9.41 \times 10-4$ \\
Gompertz & 94.69 & $1.86 \times 10-4$ & 92.84 & $1.5 \times 10-4$ & 93.75 & $3.68 \times 10-4$ \\
\hline
\end{tabular}

$R^{2}$ : coefficient of determination between predicted and observed values; RMS: residual mean square.

\section{SPATIAL ARRANGEMENT OF DISEASE}

\section{Analysis of doublet}

By the analysis of doublet we found an aggregated spatial arrangement $(\mathrm{Z} \geq 1.64 ; \mathrm{P}=0.05)$ of sick plants starting from the second evaluation in $100 \%$ rows of all three plots (Table II).

Analysis of dynamics and structure of outbreaks (ADEF)

Plants with stem bleeding symptoms immediately adjacent in the pattern of vertical, horizontal or diagonal closeness were considered outbreak sources (Bergamin Filho et al. 2004).

The percentages of sick plants (PPD) corresponding to plots 1,2 and 3 were 1.92, 0.82, and $1.65 \%$ respectively in the first assessment, and 20.16, 12.89 , and $22.77 \%$ in the last evaluation after two years (Table III). The highest number of outbreaks per unit (NFU) was observed in the first evaluations in all plots. As PPD increased, NFU reduced and the mean number of plants per outbreak (NMPF) increased. This fact indicates that, in general, the epidemic started in isolated plants, which acted as inoculum sources to adjacent healthy plants.

A study on citrus sudden death has shown that in plots with up to $2 \%$ symptomatic plants, $85 \%$ outbreaks developed from a single plant, while in cases with up to $10 \%$ incidence over $65 \%$ were single outbreaks (Gottwald et al. 1996). According to the authors, epidemic onset of citrus sudden death occurs through isolated plants, which was also reported for citrus variegated chlorosis (Laranjeira et al. 1998, Nelson 1996, Nunes et al. 2001). This positive relationship between aggregation and incidence of symptomatic plants is consistent with the hypothetical behavior of vectors from external sources, which introduce the infectious disease in the plot. As vectors reach the area they spread through trees, which initially show a typically random spatial pattern of symptomatic plants. As vectors move inside the plot, especially through adjacent or neighboring trees, the aggregation of symptomatic plants increases (Jesus Junior et al. 2004). Thus, the beetle Rhynchophorus palmarum could be acting as a stem bleeding vector and spreading the disease through the field, which results in aggregation of sick plants near the outbreak source.

In the case of blister spot, the authors found a total of 10 outbreaks with average 2.5 plants/ outbreak, and high number of single outbreaks representing 52\% sick plants (Ferreira et al. 2009). Blister spot of coffee may be spread by sick seedlings that become adult plants in the field (Ferreira et al. 2009).

Analysis of outbreak shapes (IFF) in outbreak sources formed by a single plant showed IFF equal to 1.0 , indicating isodiametric outbreaks. In other outbreaks and evaluations, IFF was greater than 1.0 , indicating longer outbreaks between crop rows (Table III). 
TABLE II

Spatial arrangement of coconut stem bleeding analyzed by doublet test in Platô de Neópolis, state of Sergipe, from July 2009 to May 2011.

\begin{tabular}{|c|c|c|c|c|c|c|c|}
\hline $\begin{array}{c}\text { Evaluation } \\
\text { (month/year) }\end{array}$ & Plot & D & $\mathbf{m}$ & $\mathbf{E}(\mathbf{D})$ & $\mathrm{S}(\mathrm{D})$ & Z(D) & $\begin{array}{l}\text { Spatial } \\
\text { Pattern }\end{array}$ \\
\hline \multirow{3}{*}{ jul/09 } & 1 & 0 & 14 & 0.250 & 0.241 & 0.510 & Random \\
\hline & 2 & 0 & 6 & 0.041 & 0.041 & 2.278 & Aggregate \\
\hline & 3 & 0 & 12 & 0.181 & 0.176 & 0.761 & Random \\
\hline \multirow{3}{*}{ sep/09 } & 1 & 23 & 45 & 2.716 & 2.398 & 13.422 & Aggregate \\
\hline & 2 & 2 & 9 & 0.099 & 0.097 & 7.726 & Aggregate \\
\hline & 3 & 8 & 22 & 0.634 & 0.598 & 10.175 & Aggregate \\
\hline \multirow{3}{*}{ nov/09 } & 1 & 31 & 53 & 3.781 & 3.260 & 15.352 & Aggregate \\
\hline & 2 & 6 & 14 & 0.250 & 0.241 & 12.737 & Aggregate \\
\hline & 3 & 18 & 34 & 1.539 & 1.403 & 14.320 & Aggregate \\
\hline \multirow{3}{*}{ jan/10 } & 1 & 39 & 60 & 4.856 & 4.101 & 17.107 & Aggregate \\
\hline & 2 & 12 & 20 & 0.521 & 0.494 & 17.036 & Aggregate \\
\hline & 3 & 37 & 56 & 4.225 & 3.611 & 17.511 & Aggregate \\
\hline \multirow{3}{*}{$\operatorname{mar} / 10$} & 1 & 43 & 65 & 5.706 & 4.748 & 17.345 & Aggregate \\
\hline & 2 & 16 & 27 & 0.963 & 0.895 & 16.419 & Aggregate \\
\hline & 3 & 42 & 74 & 7.410 & 5.999 & 14.326 & Aggregate \\
\hline \multirow{3}{*}{$\mathrm{may} / 10$} & 1 & 67 & 92 & 11.484 & 8.794 & 18.889 & Aggregate \\
\hline & 2 & 30 & 46 & 2.840 & 2.500 & 17.496 & Aggregate \\
\hline & 3 & 61 & 99 & 13.309 & 9.969 & 15.263 & Aggregate \\
\hline \multirow{3}{*}{ jul/10 } & 1 & 68 & 98 & 13.040 & 9.798 & 17.718 & Aggregate \\
\hline & 2 & 33 & 57 & 4.379 & 3.731 & 15.076 & Aggregate \\
\hline & 3 & 68 & 109 & 16.148 & 11.715 & 15.295 & Aggregate \\
\hline \multirow{3}{*}{ sep/10 } & 1 & 77 & 108 & 15.852 & 11.537 & 18.150 & Aggregate \\
\hline & 2 & 37 & 67 & 6.066 & 5.017 & 14.035 & Aggregate \\
\hline & 3 & 74 & 120 & 19.588 & 13.712 & 14.829 & Aggregate \\
\hline \multirow{3}{*}{ nov/10 } & 1 & 84 & 117 & 18.617 & 13.160 & 18.161 & Aggregate \\
\hline & 2 & 38 & 73 & 7.210 & 5.855 & 12.931 & Aggregate \\
\hline & 3 & 83 & 131 & 23.361 & 15.767 & 15.145 & Aggregate \\
\hline \multirow{3}{*}{ jan/11 } & 1 & 89 & 128 & 22.299 & 15.202 & 17.236 & Aggregate \\
\hline & 2 & 41 & 81 & 8.889 & 7.044 & 12.287 & Aggregate \\
\hline & 3 & 93 & 145 & 28.642 & 18.438 & 15.105 & Aggregate \\
\hline \multirow{3}{*}{ mar/11 } & 1 & 92 & 136 & 25.185 & 16.716 & 16.464 & Aggregate \\
\hline & 2 & 45 & 82 & 9.111 & 7.198 & 13.564 & Aggregate \\
\hline & 3 & 100 & 156 & 33.169 & 20.556 & 14.851 & Aggregate \\
\hline \multirow{3}{*}{ may/11 } & 1 & 100 & 147 & 29.440 & 18.822 & 16.379 & Aggregate \\
\hline & 2 & 50 & 94 & 11.992 & 9.125 & 12.748 & Aggregate \\
\hline & 3 & 105 & 166 & 37.572 & 22.480 & 14.327 & Aggregate \\
\hline
\end{tabular}

m: number of infected plants; D: number of doublets; E(D): expected doublets; S(D): standard deviation, Z(D): doublet pattern normal distribution. 
TABLE III

Analysis of dynamics and structure of outbreak sources (ADEF) in three plots of dwarf coconut palms with 729 trees each.

\begin{tabular}{|c|c|c|c|c|c|c|c|c|c|}
\hline Evaluation & Plot & PPD & NF & NFU & NMPF & If & Ic & IFF & ICF \\
\hline \multirow{3}{*}{ jul/09 } & 1 & 1.92 & 13 & 12 & 1.08 & 1.00 & 1.00 & 1.00 & 1.08 \\
\hline & 2 & 0.82 & 5 & 4 & 1.20 & 1.20 & 1.00 & 1.20 & 1.00 \\
\hline & 3 & 1.65 & 12 & 12 & 1.00 & 1.00 & 1.00 & 1.00 & 1.00 \\
\hline \multirow{3}{*}{ sep/09 } & 1 & 6.17 & 11 & 5 & 4.09 & 2.09 & 1.95 & 1.07 & 1.00 \\
\hline & 2 & 1.23 & 6 & 4 & 1.50 & 1.33 & 1.00 & 1.50 & 1.50 \\
\hline & 3 & 3.02 & 11 & 2 & 2.00 & 1.73 & 1.00 & 1.73 & 1.16 \\
\hline \multirow{3}{*}{ nov/09 } & 1 & 7.27 & 11 & 5 & 4.82 & 2.55 & 1.45 & 1.76 & 1.30 \\
\hline & 2 & 1.92 & 5 & 3 & 2.80 & 1.60 & 1.20 & 1.33 & 1.46 \\
\hline & 3 & 4.66 & 9 & 1 & 3.78 & 2.67 & 1.22 & 2.19 & 1.16 \\
\hline \multirow{3}{*}{$\mathrm{jan} / 10$} & 1 & 8.23 & 10 & 3 & 6.00 & 2.90 & 1.50 & 1.93 & 1.38 \\
\hline & 2 & 2.74 & 5 & 0 & 4.00 & 2.40 & 1.20 & 2.00 & 1.39 \\
\hline & 3 & 7.68 & 10 & 2 & 5.60 & 3.80 & 1.20 & 3.17 & 1.23 \\
\hline \multirow{3}{*}{$\operatorname{mar} / 10$} & 1 & 8.92 & 9 & 3 & 7.22 & 3.33 & 1.67 & 1.99 & 1.30 \\
\hline & 2 & 3.70 & 5 & 0 & 5.40 & 3.20 & 1.40 & 2.29 & 1.21 \\
\hline & 3 & 10.15 & 9 & 0 & 8.22 & 4.87 & 1.67 & 2.92 & 1.01 \\
\hline \multirow{3}{*}{$\mathrm{may} / 10$} & 1 & 12.62 & 5 & 0 & 18.40 & 5.20 & 2.20 & 2.36 & 1.61 \\
\hline & 2 & 6.31 & 7 & 0 & 6.57 & 3.86 & 1.43 & 2.70 & 1.19 \\
\hline & 3 & 13.58 & 10 & 1 & 9.90 & 5.10 & 1.90 & 2.68 & 1.02 \\
\hline \multirow{3}{*}{ jul/10 } & 1 & 13.44 & 7 & 3 & 14.00 & 5.00 & 2.43 & 2.06 & 1.15 \\
\hline & 2 & 7.82 & 7 & 0 & 8.14 & 4.14 & 1.71 & 2.42 & 1.15 \\
\hline & 3 & 14.95 & 10 & 0 & 10.90 & 5.10 & 2.10 & 2.43 & 1.02 \\
\hline \multirow{3}{*}{ sep/10 } & 1 & 14.81 & 8 & 1 & 13.50 & 4.13 & 2.40 & 1.72 & 1.36 \\
\hline & 2 & 9.19 & 10 & 3 & 6.70 & 3.40 & 1.70 & 2.00 & 1.16 \\
\hline & 3 & 16.46 & 11 & 1 & 10.90 & 4.82 & 2.00 & 2.41 & 1.13 \\
\hline \multirow{3}{*}{ nov/10 } & 1 & 16.05 & 7 & 0 & 16.71 & 5.14 & 2.57 & 2.00 & 1.26 \\
\hline & 2 & 10.01 & 9 & 1 & 8.11 & 3.67 & 1.78 & 2.06 & 1.24 \\
\hline & 3 & 17.97 & 10 & 0 & 13.10 & 5.70 & 2.30 & 2.48 & 1.00 \\
\hline \multirow{3}{*}{ jan/11 } & 1 & 17.56 & 7 & 0 & 18.29 & 4.29 & 3.14 & 1.37 & 1.36 \\
\hline & 2 & 11.11 & 9 & 0 & 9.00 & 4.11 & 2.11 & 1.95 & 1.04 \\
\hline & 3 & 19.89 & 10 & 0 & 14.50 & 6.20 & 2.40 & 2.58 & 0.97 \\
\hline \multirow{3}{*}{$\operatorname{mar} / 11$} & 1 & 18.66 & 8 & 1 & 17.00 & 4.88 & 2.88 & 1.69 & 1.21 \\
\hline & 2 & 11.25 & 8 & 1 & 10.25 & 3.88 & 2.38 & 1.63 & 1.11 \\
\hline & 3 & 21.40 & 10 & 0 & 15.60 & 6.60 & 2.50 & 2.64 & 0.95 \\
\hline \multirow{3}{*}{ may/11 } & 1 & 20.16 & 6 & 0 & 24.50 & 6.67 & 3.17 & 2.10 & 1.16 \\
\hline & 2 & 12.89 & 8 & 0 & 11.75 & 3.88 & 2.50 & 1.55 & 1.21 \\
\hline & 3 & 22.77 & 12 & 0 & 13.83 & 5.92 & 2.42 & 2.45 & 0.97 \\
\hline
\end{tabular}

PPD: percentage of sick plants; NF: number of outbreaks; NFU: number of single outbreaks; NMPF: average number of plants per outbreak; Ic: number of sick plants in the largest column; If: number of sick plants in the longest row; IFF: outbreak shapes; ICF: compression ratio of outbreaks. 
Citrus sudden death showed trends of IFF (outbreak shapes) values near 1.0, especially in cases of high number of single outbreaks (Jesus Junior et al. 2004). In the case of citrus variegated chlorosis (CVC), most plants in crop rows showed elliptical shape (Laranjeira et al. 1998, Nelson 1996). Likewise, (Ferreira et al. 2009, Jesus Júnior and Bassanezi 2004) elliptical shape was found in studies on the structure and dynamics of outbreaks for citrus sudden death (CSD) and blister spot respectively. Many authors correlate the spread of disease within crop rows to the closeness of plants as compared to the distance between rows (Laranjeira et al. 1998, Nelson 1996, Jesus Júnior and Bassanezi 2004, Ferreira et al. 2009). As in this case the distance between coconut palms within the row was equal to the distance between rows, cultural practices along crop rows, such as pruning, fruit harvest, and application of pesticides are not primarily responsible for the spread of disease in the field, which makes a vector involvement more evident in the process.

More compact outbreaks show ICF (compression ratio per outbreak) values close to 1.0 whereas less compact ones have lower values (Nelson 1996). In our study, increased NMPF (average number of plants per outbreak source) and decreased ICF (compression ratio per outbreak) remaining close to 1.0 during evaluations indicate compact outbreaks and aggregation of plants belonging to the outbreak sources (Table 3 ). This aggregation of coconut palms with stem bleeding symptoms corroborates the idea that the primary mode of transmission is via insect vector. Similar results were found for citrus sudden death (CSD) and citrus variegated chlorosis (CVC) (Laranjeira et al. 1998, Jesus Junior et al. 2004).

The dynamics and structure of stem bleeding outbreak sources showed similarity to other biotic diseases spread by vectors (Gottwald et al. 1989, 1995, 1996, 1998, Van de Lande 1993, Jeger 1990, Laranjeira et al. 1998, Jesus Junior et al. 2004).

In this study, the presence of multiple outbreaks within plots may be related to survival chlamydospores produced by the pathogens.

Stem bleeding was responsible for large aggregations of sick plants (Figure 3), indicating that infected plants were used as outbreak sources for subsequent infections (auto infections spread from plant to plant). This fact also showed that secondary inoculants were spread over short distances either by vectors, human handling of sick and then healthy plants, or contact between contaminated adjacent roots.

\section{RESUMO}

A resinose do coqueiro, causada por Thielaviopsis paradoxa, constitui uma importante doença do coqueiro no estado de Sergipe. A compreensão do comportamento epidemiológico da resinose é fundamental para o estabelecimento de estratégias de controle mais eficientes. Neste contexto o presente trabalho teve como objetivo caracterizar o progresso temporal e a distribuição espacial da resinose em um pomar comercial sob condições naturais de infecção de Neópolis, Sergipe. Foram selecionados 3 talhões com 729 plantas cada, onde as plantas foram avaliadas a cada dois meses quanto à incidência da doença. $\mathrm{Na}$ análise temporal, o modelo Monomolecular foi o que melhor se ajustou aos dados de incidência da resinose, representando bem a dinâmica temporal da doença durante o período experimental. $\mathrm{O}$ padrão espacial da resinose variou no decorrer do tempo, com infecções iniciais apresentando padrão aleatório, evoluindo para agregado no decorrer das avaliações, indicando que a doença pode ter sido originada de estruturas de sobrevivência no patógeno, seguidas de autoinfecções decorrentes da disseminação planta-a-planta, seja pelo homem, pelo contato entre raízes ou pelo vetor Rhynchophorus palmarum.

Palavras-chave: coqueiro, epidemiologia, resinose, Thielaviopsis paradoxa. 
July/2009

Plot 1
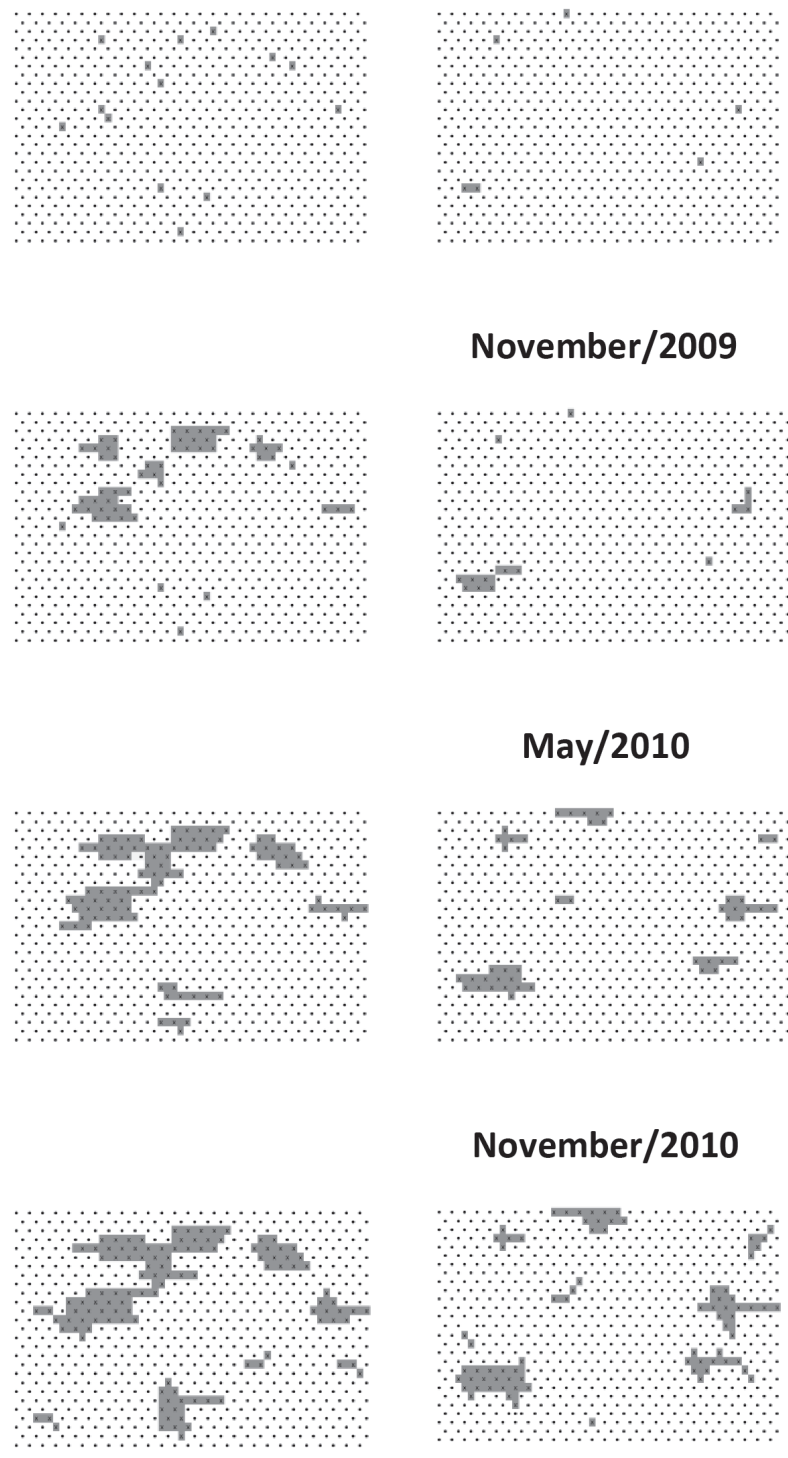

\section{May/2011}

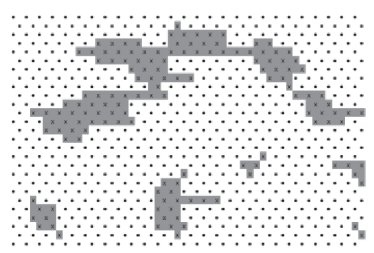

Plot 2

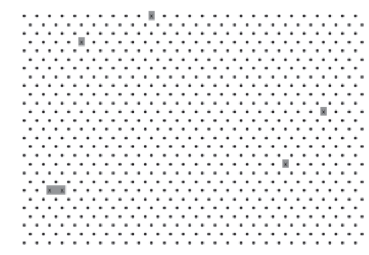

November/2009

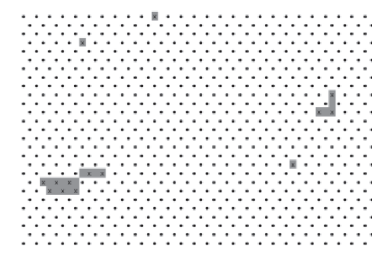

\section{May/2010}

\section{November $/ 2010$}
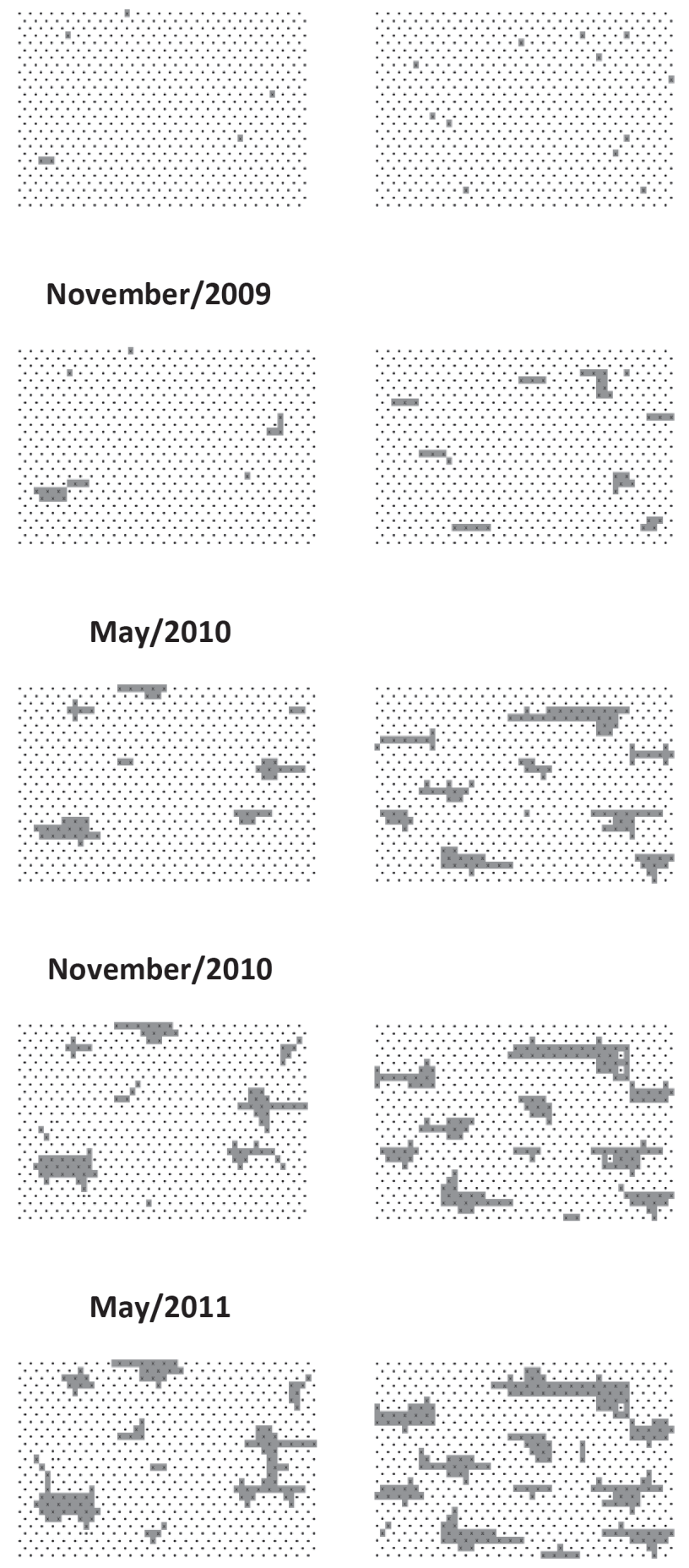

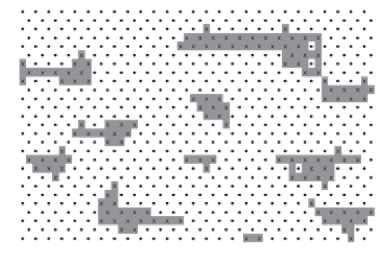

Figure 3 - Outbreaks of coconut stem bleeding detected by disease symptoms in the area of Neopolis, Sergipe, Brazil. 


\section{REFERENCES}

BERGAMIN FILHO A. 1995. Avaliação de danos e perdas. In: Bergamin Filho A, Kimati H and Amorim L (Eds), Manual de fitopatologia: princípios e conceitos. São Paulo: Ceres, p. $672-690$.

Bergamin Filho A, Hau B, Amorim L and Jesus Junior WC. 2004. Análise espacial de epidemias. In: Vale FXR, Jesus Junior WC and Zambolim L (Eds), Epidemiologia aplicada ao manejo de doenças de plantas. Belo Horizonte: Editora Perfil, p. 195-240.

CAMPBell CL AND MAdDEN LV. 1990. Introduction to Plant Disease Epidemiology. New York: John Wiley \& Sons, $532 \mathrm{p}$.

COSTA-CARVALHO RR, WARWICK DRN, SOUZA PE AND CARVALHO FILHO JLS. 2011. Longevidade de Thielaviopsis paradoxa, agente causal da resinose do coqueiro em Rhynchophorus palmarum. Scientia Plena 7: 1-6.

Ferreira JB, ABreu MS AND PEREIRA IS. 2009. Análise da dinâmica e estrutura, estrutura de focos e arranjo espacial da mancha manteigosa em campo. Cienc Agrotec 33: 14-30.

GotTwald TR, Aubert B AND ZHaO XY. 1989. Preliminary analysis of citrus greening (Huanglungbin) epidemics in the People's Republic of China and French Reunion Island. Phytopathol 79: 687-693.

GotTwald TR, Avinent L, LlÁCER G, MendozA AH AND CAMBRA M. 1995. Analysis in the spatial spread of sharka (plum pox virus) in apricot and peach orchards in eastern Spain. Plant Disease 79: 266-278.

GotTwald TR, CAMBra M, MOREnO P, CAMARAsa E AND PIQUER J. 1996. Spatial and temporal analyses of citrus tristeza virus in eastern Spain. Phytopathol 86: 45-55.
GOTTWALD TR, GARNSEY SM AND BORBON J. 1998. Increase and patterns of spread of citrus tristeza virus infections in Costa Rica and the Dominican Republic in the presence of the brown citrus aphid, Toxoptera citricida. Phytopathol 88: 621-636.

JEGER MJ. 1990. Mathematical analysis and modeling of spatial aspects of plant disease epidemics. In: Kranz J (Ed), Epidemics of Plant Diseases: Mathematical Analysis and Modeling. $2^{\text {nd }}$ ed., New York: Springer, p. 53-95.

JESUS JUNIOR WC AND BASSANEZI RB. 2004. Análise da dinâmica e estrutura de focos da morte súbita dos citros. Fitopatol Bras 29: 399-405.

Jesus Junior WC, Pozza EA, VAle FXR And Aguilera GM. 2004. Análise temporal de epidemias. In: Vale FXR, Jesus Junior WC and Zambolim L (Eds), Epidemiologia aplicada ao manejo de doenças de plantas. Belo Horizonte: Perfil, p.127-191

LARANJEIRA FF, BERGAMIN FILHO A AND AMORIM L. 1998. Dinâmica e estrutura de focos da clorose variegada dos citros (CVC). Fitopatol Bras 23: 36-41.

NELSON SC. 1996. A simple analysis of disease foci. Phytopathol 86: 332-339.

Nunes WMC, Machado MA, Nunes MJC And FurTado EL. 2001. Dinâmica espacial de foco da clorose variegada dos citros (CVC) avaliada por meio da sintomatologia e serologia. Acta Scient 23: 1215-1219.

VAN DE LANDE HL. 1993. Spatio-temporal analysis of spear rot and 'marchitez sorpresiva' in African oil palm in Surinam. Netherlands J of P1 Pathol 99: 129-138.

WARWICK DRN AND PASSOS EEM. 2009. Outbreak of stem bleeding in coconuts caused by Thielaviopsis paradoxa in Sergipe, Brazil. Trop Plant Pathol 34: 175-177. 